\title{
サルコペニア肥満の評価法 〜その現状と問題点
}

\author{
真田樹 義 ${ }^{1}$, 宮 地 元 彦 $^{2}$, 石井好二郎 ${ }^{3}$, 浅 原 哲 ${ }^{4}$ \\ (1 立命館大学スポーツ健康科学部, ${ }^{2}$ 独立行政法人国立健康・栄養研究所, \\ ${ }^{3}$ 同志社大学スポーツ健康科学部， ${ }^{4}$ 独国立病院機構京都医療センター）
}

最近, サルコペニアと肥満の合併がさらなるメタボ リックシンドロームリスクを高めることが話題となって いる. Roubenoff (2000) は, 筋量の減少と体脂肪の増加 は媣く関連しているが, 両者の体組成変化の主要な要因 としては筋量の減少であるサルコペニアが重要であると 述べている ${ }^{1)}$. Schragerら（2007）は，腹囲が大きく， かつ筋力が低い被験者は, 血中炎症反応が相乗的に高い ことを報告しており，肥満とサルコペニアは両者とも炎 症反応の増加に関連することを明らかにしている2). ま たSchaapら（2006）は, 高い血中 IL-6 㧍よびC反応性蛋 白レベルは, 加齢による筋力減少のリスクを増加させる と報告している3）。これらの結果から，サルコペニアと 肥満の合併であるサルコペニア肥満は，身体的障害や生 活習慣病発症リスクをさらに助長する可能性が考えられ る。 65 歳以上の韓国人男女 565 名を対象とした韓国サル コペニア肥満研究では, DXA法による体肢筋量とCT法 による内臓脂肪面積で規定したサルコペニア肥満は, 男 性で $16.7 \%$ ，女性で $5.7 \%$ が確認されている ${ }^{4)}$.

Herberらは, 加齢によって除脂肪量が減少し, 体脂肪 量が増加した状態をサルコペニア肥満と定義している5. この報告は, 我々の知る限り, サルコペニア肥満を定義 した最も古い論文であると思われる。この研究の対象者 は, すべて肥満患者であり, BIA 法による除脂肪量の值 によって, 肥満者をサルコペニア肥満, バランス型肥満 (体重増加に見合った除脂肪量の増加を伴う肥満), 筋肉 質肥満の 3 種類に分類されている。 また, Barmgartner は，加齢によって四肢筋量が減少し，体脂肪量が増加し た状態をサルコペニア肥満と定義している ${ }^{6)}$. 彼らは, DXA 法を用いたサルコペニアの診断基準の参照值を, 世界で初めて示した研究グループで7), サルコペニア肥 満も同様にDXA 法による四肢筋量と体脂肪率に基づい て, 一般高齢者の体型を, 標準, サルコペニア, 肥満, サルコペニア肥満の 4 種類に分類した。四肢筋量は身長 の 2 乗を除した值を使用し, 健康な若年者の平均值マ イナス $2 \mathrm{SD}$ 未満をサルコペニアのカットオフ值とした。 その值は, 男性が $7.26 \mathrm{~kg} / \mathrm{m}^{2}$ 未満, 女性が $5.45 \mathrm{~kg} / \mathrm{m}^{2}$ 未 満である。体脂肪率は，一般成人の平均值を用いており，
それぞれ男性は $27 \%$ 以上，女性は $38 \%$ 以上を肥満と定義 している.この基準值に基づいたサルコペニア肥満の発 症率は, 加齢によって増加し, 80歳以上の高齢者に抢い ては一般高齢者の拈よそ10\%であったと報告している。

一方, 現在のところ, サルコペニア肥満の診断基準に 関する統一されたコンセンサスは示されていない，体組 成は加齢によって劇的に変化するとともに, サルコペニ アおよび肥満の判断基準も様々であることが, サルコペ ニア肥満の判定を一層複雑にしている. 今後の研究で, 共通の診断基準の策定が必要であると考えられる.

1) Roubenoff R: Sarcopenic obesity: does muscle loss cause fat gain? Lessons from rheumatoid arthritis and osteoarthritis. Ann NY Acad Sci 904: 553-7, 2000

2) Schrager MA, Metter EJ, Simonsick E, Ble A, Bandinelli S, Lauretani F, et al.: Sarcopenic obesity and inflammation in the InCHIANTI study. J Appl Physiol 102: 919-25, 2007

3) Schaap LA, Pluijm SM, Deeg DJ, Visser M: Inflammatory markers and loss of muscle mass (sarcopenia) and strength. Am J Med 119: 526 e9-17, 2006

4) Lim S, Kim JH, Yoon JW, Kang SM, Choi SH, Park YJ, et al.: Sarcopenic obesity: prevalence and association with metabolic syndrome in the Korean Longitudinal Study on Health and Aging (KLoSHA). Diabetes Care 33: 1652-4, 2010

5) Heber D, Ingles S, Ashley JM, Maxwell MH, Lyons $\mathrm{RF}$, Elashoff RM: Clinical detection of sarcopenic obesity by bioelectrical impedance analysis. Am J Clin Nutr 64: 472S-7S, 1996

6) Baumgartner RN: Body composition in healthy aging. Ann N Y Acad Sci 904: 437-48, 2000

7) Baumgartner RN, Koehler KM, Gallagher D, Romero L, Heymsfield SB, Ross RR, et al.: Epidemiology of sarcopenia among the elderly in New Mexico. Am J Epidemiol 147: 755-63, 1998 